\title{
The Relationship between Iranian EFL Teachers' Self-efficacy, their Personality and Students' Motivation
}

Masoud Khalili Sabet, Saeedeh Dehghannezhad*, Abdorreza Tahriri

Department of English Language and Literature, University of Guilan, Iran

Corresponding author: Saeedeh Dehghannezhad, E-mail: saeedeh_dehghannezhad@yahoo.com

\section{ARTICLE INFO}

Article history

Received: July 30, 2018

Accepted: September 04, 2018

Published: October 31, 2018

Volume: 6 Issue: 4

Conflicts of interest: None

Funding: None

\begin{abstract}
A growing body of evidence suggests that teachers play a significant role in the process of foreign language teaching and learning. On the other hand, motivation is one of the most important pre-requisites of foreign language learning which can be influenced by many teacher-related factors such as teachers' personality characteristics and their self-efficacy beliefs. Therefore, this study was conducted to examine the relationship between Iranian EFL teachers' self-efficacy, their personality and students' motivation. Participants included 25 EFL teachers teaching in different language institutes and 75 EFL students learning English in those institutes. In this study, three instruments were used for data collection: Teachers' Sense of Efficacy Scale (TSES) developed by Tschannen-Moran and Hoy (2001), Neuroticism-Extraversion-Openness FiveFactor Inventory (NEO-FFI), and Students' Motivation Questionnaire designed by Mojavezi and Tamiz (2012). To analyze the data, Pearson correlation was conducted on the variables using the computer program of SPSS 22. Results of the analysis showed that there was a significant positive correlation between teachers' self-efficacy and students' motivation $(r=.591, p=.002<.05)$. The other finding of the study was that one of the NEO-FFI variables, conscientiousness, was found to be significantly in correlation with students' motivation $(r=.413, p=.040<.05)$. Results of the study and their pedagogical implications were discussed and recommendations for further research were also made.
\end{abstract}

Key words: EFL Teachers, Personality, Self-efficacy, Students' Motivation, Teacher Self-efficacy

\section{INTRODUCTION}

Research shows that teachers play an important role in students' academic achievement and motivation, especially in EFL contexts. According to Marzano and Pickering (2003) teacher is the most important factor influencing students' academic achievement (as cited in Mozaffari \& Ghodratinia, 2015). In fact, successful teachers believe that they are able to make a difference in students' learning outcomes which let them choose more appropriate teaching techniques (Gibbs, 2002 as cited in Mashhady, 2013). That is why the main concern in language institutes is employing knowledgeable teachers who believe in their capability to enhance students' achievement (Mozaffari \& Ghodratinia, 2015). Harkin and Turner (1997) believe that different teachers may use distinct techniques or methods in the same context depending on their personality types, teaching styles and beliefs in their abilities to influence learners' achievement (as cited in Alibakhshi, 2011). Therefore, teachers' self-efficacy and personality are among important research areas in TEFL.

Further, it can be argued that individuals are different in learning a new language. Attitudes, personality factors, age/ gender differences, anxiety, cognitive factors, and a lot of other factors are examples of such individual differences. One of the distinctive factors refers to motivation which is one of the most effective pre-requisites of successful teaching-learning process in all contexts (Ames, 1987 as cited in Zarabian, Farajollahi, Yousefpour, \& Sajadiseresht, 2015). As a result, this study focuses on investigating the relationship between EFL teachers' self-efficacy/personality and their students' motivation.

There has been substantial research (Al Haj, 2011; Alizadeh, 2016; and Bahous, Bacha, \& Nabhani, 2011, among others) undertaken on the role of motivation in students' foreign language learning which shows that some of the EFL students are not motivated enough for doing their homework and independent studies. In other words, they do not show enough motivation for learning English. In fact, they are "reluctant to get immersed into the language learning process" (Fatemi, Ganjali, \& Kafi, 2015, p. 189). In addition, in many cases, they encounter so many obstacles in learning English that make them demotivated to learn English (Al Kaboody, 2013).

Besides, regarding the crucial role of teachers in the process of foreign language learning, it has become challenging to consider the probable effect of teachers' self-efficacy and 
personality in students' motivation or demotivation. Further, no known empirical research in the context of Iran has focused on exploring relationships between EFL teachers' personality types, self-efficacy levels and private language institute students' levels of motivation. So, regarding the above-mentioned problems, the present study aimed to explore the relationship between teachers' self-efficacy, their personality and students' motivation. Thus, the current study tried to answer the following research questions:

1. Is there any relationship between English language teachers' self-efficacy and their students' motivation for learning?

2. Is there any relationship between English language teachers' personality types and their students' motivation for learning?

\section{LITERATURE REVIEW}

\section{Self-efficacy}

The concept of self-efficacy was first mentioned by Bandura. Bandura (1997) defined self-efficacy as "the belief in one's own ability to successfully accomplish something" (p. 15). In his idea, people usually try things they think they can do. However, he believes people with a high level of self-efficacy believe they can do even challenging tasks. According to Pajares (2002), self-efficacy beliefs influence human motivation, well-being and personal accomplishment. He thinks this is the reason people persevere in the face of difficulties to achieve their desired outcomes.

According to Bandura (1977) self-efficacy beliefs can vary from one person to another on several dimensions. The three areas of difference include: magnitude (level), generality, and strength. First, self-efficacy beliefs differ in magnitude which refers to the perception of the difficulty of the tasks. Second, they also vary in generality which refers to "the degree to which efficacy beliefs about one task may generalize across a range of similar activities in the same or other domains of functioning" (Dellinger, Bobbett, O1ivier, \& Ellett, 2008 as cited in Moradkhani, 2009, p. 10). Third, self-efficacy beliefs differ in strength. Those people who possess strong beliefs in the ability to do a task will not give up in the face of difficulties, whereas those who possess weak beliefs will get easily disappointed in such situations. So, there are different kinds of people based on their self-efficacy beliefs (Bandura, 1977).

Self-efficacy beliefs are based on four main sources of information: performance accomplishments (also referred to as 'mastery experience'); vicarious experience (or 'role-modeling'); verbal persuasion; and somatic and emotional states (Bandura, 1977 \& 1994). The first source, performance accomplishments, is the most influential of all which is based on the individuals' mastery experiences. All people have mastery experiences. In fact, when people attempt to do something and succeed, they have mastered it. This mastery helps them believe they can do something new which is similar to the behavior they have already accomplished successfully (Bandura, 1977). The second source, vicarious experience, refers to the observation of the successes and failures of others (models) who are similar to one's self. That's why this source of information is also called role-modeling (Bandura, 1977). The third source of self-efficacy refers to verbal or social persuasions that individuals receive from others. These persuasions try to convince people who are not sure about their capabilities that they have enough skills to be successful at a certain task (Bandura, 1986, 1997, as cited in Rashidi \& Moghadam, 2014). Actually, when people are persuaded that they can accomplish a certain task, they are more eager to do the task and "mobilize greater effort" (Bandura, 1994, p. 3). The last source, physiological and emotional states, such as stress, anxiety, excitement, and worry can also have an effect on forming self-efficacy beliefs because people judge their capabilities based on these states. In other words, the physical and emotional states that occur when someone contemplates doing a task provide cues about the likelihood of success or failure (Bandura, 1994).

\section{Teacher Self-efficacy}

As the concept of self-efficacy is extended to teaching context, teacher's sense of efficacy can be defined as "teachers' judgments on their capabilities to bring about student change even in those difficult or unmotivated students" (Chacón, 2005 as cited in Moradkhani, 2009, p. 6). More specifically, it can be inferred that high efficacious teachers feel so confident that they can make favorable changes in even those difficult or unmotivated students. The reverse can be said about teachers with low levels of self-efficacy who feel disappointed when dealing with such students. According to Bandura (1994) teacher self-efficacy shows how confident a teacher is to his or her capabilities to raise his or her students' learning (as cited in Mojavezi \& Tamiz, 2012). In a similar definition, Distad and Brownstein (2004) describe teacher self-efficacy as a teacher's "belief that he or she has the skills necessary to effect positive changes in student learning" (as cited in Shangarffam \& Poshti, 2011, p. 177).

High efficacious teachers show greater enthusiasm for teaching, feel more commitment to teaching and are more likely to stay in the teaching profession (Tschannen-Moran \& Hoy, 2001 as cited in Gavora, 2010). On the contrary, teachers with low sense of efficacy are reported to "show weak commitment to teaching, spend less time in subject matters in their areas of perceived inefficacy, and devote less overall time to academic matters" (Bandura, 1995 as cited in Akbari, Kiany, Naeeni, \& Karimi Allvar, 2008, p. 7).

Research on the measurement of teacher efficacy began with the studies conducted by the RAND Corporation and based on the influence of Rotter's locus of control theory (Armor et al., 1976 as cited in Looney, 2003; Henson, 2002 as cited in White, 2009). According to Tschannen-Moran and Hoy (2001), the RAND measure consisted of just two items which were used to assess internal or external control of reinforcement and the sum of the two items was known as teacher efficacy. Researchers continued their efforts to remove the shortcomings of the previous scales and develop a more comprehensive instrument. One of these efforts led to the development of the Teachers' Sense of Efficacy Scale (TSES) by Tschannen-Moran and Hoy (2001). 
In fact, TSES which has been used to measure teacher efficacy in many researches consists of three dimensions of teacher efficacy: efficacy for instructional strategies, student engagement, and classroom management.

\section{Personality}

Mayer (2007) defined personality as "a system of parts that is organized, develops and expressed in a person's actions" (p. 1). He further clarified the system of parts as components such as "motives, emotions, mental models, and the self" (Mayer, 2007, p. 1). In another definition, Atkinson, Smith, Daril, Hoksma, and Nolen (1983), state that "personality refers to certain patterns of behaviors and thinking ways which determine individual's adaptation to the environment" (as cited in Zarabian et al., 2015, p. 816). Since, in the area of teaching and learning, persons deal with individuals as teachers and learners, personality is supposed to be an effective factor. According to Sronge, Tucker, and Hindman (2004) 'teacher's personality refers to inner-qualities of a teacher, observed from the teacher's expression of values, beliefs, behavior, and attitude" (as cited in Hashim, Alam, \&Yusoff, 2014, p. 103).

With regard to the measurement of personality, some models were produced which have been used in many research studies. One of the most comprehensive models is the Five-Factor-Model of personality known as the big five suggesting that there are five broad dimensions that constitute people's personalities. These five dimensions include openness to experience, conscientiousness, extroversion, agreeableness, and neuroticism, mostly identified with the useful acronym OCEAN (Cherry, 2017). So, the current research study is going to use the big five personality model to measure EFL teachers' personality types.

Openness to experience refers to the desire to "explore, detect and enjoy abstract and sensory information" (DeYoung, 2010 as cited in Bjurberg, 2014, p. 11). In other words, it refers to an open-minded personality which is interested in new things (Costa \& McCrae, 1992 as cited in Leephaijaroen, 2016) rather than a narrow-minded personality which is so simple (Costa \& McCrae, 1992 as cited in Mammadov, 2016). In fact, individuals who are open to experience show more interest in novel ideas and try to experience fortunate and unfortunate emotions deeply (Jonassaint et al, 2010 as cited in Dawson \& Shih, 2015).

Conscientiousness refers to the tendency to control, manage, and direct impulses (Keshavarzi \& Amiri, 2016). It is also defined as the ability to regulate behavior in order to follow non-immediate goals and work within the rules (DeYoung, 2010 as cited in Bjurberg, 2014). In fact, it concerns "the individuals' degree of persistence, organization, and motivation in directed behaviors" (Ghazi, Shahzada, \& Ullah, 2013, p. 438). Similarly, Costa and McCrae (1992) refer to conscientiousness as a reliable personality which is "responsible, nice and orderly, stern at work, and self-disciplined" (as cited in Leephaijaroen, 2016, p. 105).

Extraversion has been found to be a significant factor in most of the important taxonomies of personality traits (Mammadov, 2016). Costa and McCrae (1992) define extraversion as a personality which is dependent on making relationships with others (as cited in Leephaijaroen, 2016). However, sociability is not the only quality which is assessed on the domain of extraversion. The other basic quality is energy which differentiates between extraversts and introverts (Costa, McCrae, \& Holland, 1992 as cited in Ghazi et al., 2013). In fact, in this domain traits such as talkativeness, assertiveness, and high activity levels are contrasted with traits such as silence, passivity, and reserve (Goldberg, 1993 as cited in Mammadov, 2016).

Agreeableness assesses an individual's attitudes towards others (Piedmont, 1998 as cited in Ghazi et al., 2013). Therefore, it is said to be an interpersonal trait dimension which measures the degree of compatibility of a person with others or the degree of interest of a person in getting along with other people (Dawson \& Shih, 2015). According to Costa and McCrae (1992) agreeableness is a kind of accommodating personality and those having this personality tend to show more cooperation, warmth, and reliability (as cited in Leephaijaroen, 2016).

Ayodele (2013) defines neuroticism as "a tendency to easily experience unpleasant emotions such as anger, anxiety, depression, vulnerability, hostility and impulsiveness" (p. 29). Neuroticism is one of the traits that is assumed to be negative and researchers usually reverse it and call it "emotional stability", a personality that gives the individuals the ability to deal successfully with any tension (Costa and McCrae, 1992 as cited in Leephaijaroen, 2016).

\section{Motivation for Learning}

Williams \& Burden (1997) defined motivation as "a state of temporary or prolonged goal-oriented behavior which individuals actively choose to engage in" (p. 94). In fact, motivation grants energy and power to human being and provides direction (Dörnyei, 1998 as cited in Gilakjani, Leong, \& Sabouri, 2012).

When talking about foreign language education, almost all scholars agree about the fact that "motivation is a crucial affective factor for students' success or failure in learning in general and in acquiring other languages in particular" (Naima, 2013, p. 6). If the learners want to be motivated, they must have an objective which can be learning a foreign language (Gardner, 1985 as cited in Gilakjani et al., 2012). More specifically, motivation can be identified as the learners' orientation regarding the second language learning (Crookes \& Schmidt, 1991 as cited in Gilakjani et al., 2012). In fact, motivation is the key element which creates learning and, hence, functions as a powerful force that helps learners keep on the long process of foreign language learning (Shiri, 2015).

In the current study, EFL students' motivation for learning would be investigated in four categories. These four categories include students' intrinsic motivation, students' extrinsic motivation, students' attitudes toward learning English, and finally students' opinions about the teacher. In fact, intrinsic motivation refers to "the motivation to engage in an activity (foreign language learning) because that activity is enjoyable and satisfying to do" (Gilakjani et al., 2012, p. 11). However, 
extrinsic motivation refers to the "actions which are carried out to achieve some instrumental ends, such as, earning a reward or avoiding a punishment" (Gilakjani et al., 2012, p. 11). In the third category, students reveal their ideas about learning English. For example, they mention whether they enjoy and love learning English or they learn it reluctantly, whether they look forward to going to English class, and how much they plan to learn English. In the last category, students present their opinions about their English teacher. For instance, they say whether their teachers are interested in English and teaching English, whether they try to make students motivated, and how much they provide feedback to students when they have difficulty in understanding the lessons (Mojavezi \& Tamiz, 2012).

\section{Related Studies}

A number of studies have investigated the role of teachers' self-efficacy on their students' achievement and motivation. For instance, Moradkhani (2009) examined the effect that language teachers' self-efficacy and academic degree could have on students' achievement. The results indicated that teachers with higher sense of efficacy helped their students reach higher academic achievement. It was also concluded that there was a significant relationship between teachers' self-efficacy and their academic degree.

In addition, in a study conducted by Mojavezi and Tamiz (2012) the effect of eighty senior high school teachers' self-efficacy beliefs on one hundred and fifty senior high school students' motivation and achievement was investigated. The results of the study revealed that students' motivation and achievement were positively under the influence of teachers' self-efficacy beliefs.

Similarly, Saeidi and Kalantarpour (2011) carried out a study to explore "the relationship between Iranian EFL teachers' self-efficacy and students' language achievement" (p. 1562). The sample of this study consisted of 45 male and female EFL teachers of Tabriz Islamic Azad University and their students. The result of this study indicated a significant positive correlation between teachers' self-efficacy beliefs and students' achievement. Saeidi and Kalantarpour (2011) concluded that teachers who believe in the strong influence of teaching on students' learning build a higher expectation of their students' academic success.

Using the information acquired from an extensive literature review on the basis of the positive effect of high efficacious teachers on their students' achievement, Freeman (2008) conducted a qualitative project in the US "to provide teachers with methodologies and powerful strategies to improve teacher efficacy and thereby increase student achievement" (p. 26). In this project, the researcher created a power point presentation which was presented to five teachers and one administrator for review. According to Freeman (2008), all the participants of the study agreed that the information in the power point presentation would be helpful for administrators, teachers, and especially efficacious teachers so that they could retain their talents, skills, and efforts.

There have been also some studies which focused on the impact of teachers' personality on their students' achievement and motivation. For example, in a study carried out by Keshavarzi and Amiri (2016), the effect of teachers' personality and corrective feedback on EFL learners' motivation was explored. For this purpose, the researchers collected data on a sample of 45 teachers and 298 students. The results showed that there was a negative relationship between neuroticism and corrective feedback at in both teachers and students which means that higher neuroticism was associated with lower corrective feedback. The researchers came into this conclusion that some specific personality could lead to improvement in learning.

In another study done by Zarabian et al. (2015) "the relationship between teachers' personality types and female high school third graders' achievement motivation in Mashhad" (p. 815) was investigated. In this study, 120 teachers and 350 students were selected as the participants of the study and were asked to fill out the Freedman-Rosenman's type questionnaire and Herman's achievement motivation questionnaire respectively. The result of the study revealed that students with type B teachers (having low level of competition, time urgency, and restlessness) had higher motivation.

In an effort to examine the relationship between secondary school teachers' personality in classroom and students' learning motivation, Jahangiri (2016) conducted a study with a sample consisting of 20 teachers and 80 students who were asked to fill out the classroom management strategies questionnaire and the academic motivation scale respectively. The results of the study showed that the character of the teachers (classroom management strategies) was highly responsible for the students' motivation to learn. Therefore, "teachers' personality in classroom related with students' learning motivation" (Jahangiri, 2016, p. 208).

Finally, in a study conducted in Malaysia, Hashim et al. (2014) tried to explore "whether teachers' characteristics and environmental learning factors influence students' overall communication proficiency" (p. 101). The results of this study indicated that teachers' personality can significantly determine students' English proficiency. Classroom conditions were also found to be a predictor that directly increases students' learning. Hashim et al. (2014) concluded that "teachers should therefore focus their efforts to portray delightful qualities such as integrity, respect, compassion, and sensitivity to students' need as these values essentially creates motivation to learn" (p. 112).

The above-mentioned studies and the similar ones have investigated the effect of teachers' self-efficacy beliefs and personality types mostly on university and school students' academic achievement rather than motivation. However, no known study has explored the probable effect of EFL teachers' self-efficacy beliefs and big five personality traits specifically on private language institute students' motivation especially in the context of Iran. That's why the current study was conducted to fill this gap.

\section{Methodology}

\section{Participants}

The present research study needed two groups of participants. The first group included EFL teachers and the second one included EFL students. The population of this study 
consisted of all English language teachers, teaching in different language institutes in Rasht, Iran and all the students learning English in those institutes.

Therefore, 25 male and female EFL teachers teaching in different institutes were chosen as the participants of the first group and 75 EFL students learning English in those institutes were chosen as the participants of the second group. All of the teachers who were between 24 to 47 years old agreed to take part in the study. The teaching experience of the teachers ranged from 3 to 21 years. In addition, there was variation in terms of student participants' age, gender, and level or language proficiency. Finally, it is necessary to state that in this study, all the participants were selected randomly.

\section{Instruments}

In the present study, three different instruments were used for data collection. The first instrument was Teachers' Sense of Efficacy Scale (TSES) (Tschannen-Moran \& Hoy, 2001). This instrument has two forms: the long form consisting of 24 items, and the short form consisting of 12 items. Both forms are based on a 9-point Likert-type scale including (nothing), (very little), (some influence), (quite a bit), and (a great deal) which assess teachers' self-efficacy in three dimensions: instructional strategies, student engagement, and classroom management. In this study, the long form of the TSES with the reliability of 0.94 was employed. Furthermore, Tschannen-Moran and Woolfolk Hoy (2001) examined the validity of both forms through correlation of their testing instrument to other existing measures of teacher efficacy. During the process of validation, Tschannen-Moran and Woolfolk Hoy (2001) found that the questions loaded on three factors: student engagement, instructional practices, and classroom management. In addition, the following general groupings were found about the long form:

- $\quad$ Efficacy in Student Engagement: Items 1, 2, 4, 6, 9, 12, 14,22

- $\quad$ Efficacy in Instructional Strategies: Items 7, 10, 11, 17, $18,20,23,24$

- $\quad$ Efficacy in Classroom Management: Items 3, 5, 8, 13, $15,16,19,21$

The second instrument was the NEO-Five-Factor Inventory (NEO-FFI) (Costa \& McCrae, 1992). The original version of the NEO-FFI (the long form) consists of 240 items rated on a 5-point Likert-type scale including (strongly disagree), (disagree), (neutral), (agree), (strongly agree) which is used to measure teachers' five personality dimensions; let's say openness to experience, conscientiousness, extroversion, agreeableness, and neuroticism. However, there is a shorter scale of the NEO-FFI (the short form) which contains only 60 items (12 questions per domain) and measures just the overall domains instead of all facets. The 12 items for each domain are added together to provide a total score for that personality domain. Higher scores show more characteristics of that domain. In this study, the short form of the NEOFFI was employed. This version of the NEO-FFI has been reported to have good concurrent validity with the revised version (NEO-PI-R) correlating $\mathrm{N}=0.92, \mathrm{E}=0.90, \mathrm{O}=0.91$, $\mathrm{A}=0.77$, and $\mathrm{C}=0.87$ (Costa \& McCrae, 1992). Similarly, alpha reliability for this instrument has been reported to be $\mathrm{N}=0.79, \mathrm{E}=0.79, \mathrm{O}=0.80, \mathrm{~A}=0.75$, and $\mathrm{C}=0.83$ (Costa \& McCrae, 1992).

At last, the third instrument was a motivation questionnaire designed by Mojavezi and Tamiz (2012). This questionnaire is based on a 5-point Likert-type scale which includes four parts. The first part assesses students' extrinsic motivation and the second part assesses students' intrinsic motivation. Both of these parts have been adopted from Schmidt (as cited in Mojavezi \& Tamiz, 2012). The third part which elicits information about students' attitudes toward learning English has been adopted from Gardner (as cited in Mojavezi \& Tamiz, 2012). Finally, the fourth part which seeks out information on students' opinions about the teacher has been developed by Mojavezi and Tamiz (2012). In addition, eight experts from different universities reviewed the items in the last part of the questionnaire (the students' opinions about the teacher) in order to examine the validity of this part. As a result, some items were deleted and some others were modified. In order to identify how the whole items in the questionnaire functioned, factor analysis was conducted. In fact, Mojavezi and Tamiz (2012) wanted to be sure if the items were related to each dimension of students' motivation. The result indicated that the questionnaire had four dimensions on which the items were loaded strongly. In other words, the questionnaire had four parts of items which addressed intrinsic motivation, extrinsic motivation, attitude toward English, and opinion about the teacher separately. Furthermore, Mojavezi and Tamiz (2012) reported alpha reliability of 0.85 for this instrument in their pilot study which seemed to be acceptable. Thus, this questionnaire could be used as a valid and reliable instrument in this study.

\section{Procedure}

This study was conducted in the academic year 2016-2017. The data collection was carried out in October 2017. The first group of participants consisted of 25 EFL teachers who were teaching in different language institutes in Rasht, Iran. The researcher aimed at finding out what the self-efficacy level and personality types of the teachers were. So, two questionnaires (Teachers' Sense of Efficacy Scale (TSES) and NEOFive-Factor Inventory (NEO-FFI)) were employed in order to collect the necessary data in this regard.

For each data collection session, first the aims of the study and the process of data collection were described to the teachers. The teachers were also assured that the data received from them would be publicized anonymously and their personal information would remain confidential. In addition, written informed consent was collected for all the participants before each data collection session.

Next, the teachers were explained how to fill out the two questionnaires. They were asked to answer as truthfully as possible and to ask the researcher if they had troubles understanding any item. Further, they were asked to write their names and the name of their institute on the questionnaire for being able to select some of their students randomly as the participants of the second group. Finally, the TSES and NEO-FFI were distributed among the teachers and they were 
asked to complete them. After they completed the two questionnaires they were thanked by the researcher for their time and cooperation in this study.

After the teacher participants completed the questionnaires, five students from each teacher's class were selected randomly to fill out the students' motivation questionnaire. The list of the students had been collected from each teacher participant in advance.

The second group of participants consisted of $75 \mathrm{EFL}$ students who were learning English in different language institutes in Rasht, Iran. The researcher wanted to measure the students' motivation in order to find its relationship with their teachers' self-efficacy and personality. To this end, a motivation questionnaire was used. The same procedure for collecting data from the students was carried out. After an adequate explanation on how to fill out the questionnaire, the questionnaire was distributed among the students and they were asked to complete it. Finally, all the gathered quantitative data were entered into SPSS 22 (Statistical Package for the Social Science) in order to be analyzed.

\section{RESULT AND DISCUSSION}

\section{Teacher Self-efficacy and Student Motivation}

The first research question was designed to see whether there is any relationship between English language teachers' self-efficacy and their students' motivation for learning. To investigate the correlation between teachers' self-efficacy and their students' motivation, Pearson correlation was conducted using the computer program of SPSS 22.

Table 1 shows the relationship between teachers' overall self-efficacy and their students' overall motivation. According to Cohen's guidelines for interpreting the results of the correlation coefficient presented in Table 2, the results show that there is a large correlation between teachers' overall self-efficacy and their students' overall motivation $(\mathrm{r}=.591$, $\mathrm{p}=.002<.05)$ at a statistically significant level which means that more efficacious teachers had more motivated students.

\section{Teacher Personality Types and Student Motivation}

The second research question was designed to see whether there is any relationship between English language teachers' personality types and their students' motivation for learning. Therefore, to investigate the correlation between teachers' personality types and their students' motivation, Pearson correlation was conducted using the computer program of SPSS 22

Table 3 shows the relationship between teachers' personality types and their students' overall motivation. The results show that there are not any significant correlations between teachers' personality types 'Neuroticism' $(r=-.110, p=.601$ $>.05)$, 'Extraversion' $(\mathrm{r}=.280, \mathrm{p}=.176>.05)$, 'Openness' $(\mathrm{r}=.134, \mathrm{p}=.522>.05)$, and 'Agreeableness' $(\mathrm{r}=-.069$, $\mathrm{p}=.744>.05)$ and their students' overall motivation at a statistically significant level, while there is a medium correlation between teachers' conscientiousness and their students' overall motivation $(\mathrm{r}=.413, \mathrm{p}=.040<.05)$ at a statistically significant level which means that higher conscientiousness in teachers is correlated with higher motivation in students.

Based on the aforementioned results, we come up to the conclusion that the conscientiousness personality trait of teachers turned out to be more dominant as compared to other remaining personality traits and proved to have a positive correlation with students' overall motivation.

\section{Discussion}

The current study examined the relationship between EFL teachers' self-efficacy, personality and their students' motivation. Results from the current study indicated that there is a significant positive statistical correlation between teachers' self-efficacy and their students' motivation. In other words, it was shown that the higher teacher self-efficacy, the higher student motivation. Teachers with higher sense of self-efficacy are more confident in developing students' motivation for learning. In fact, they repeatedly look for new methods and materials to reach their ideal result. Such teachers don't give up at the time of confronting student failure and try to praise their students' efforts. As a result, they have more motivated students.

These results are in consistence with the findings of the previous researches which suggested a significant correlation between teachers' sense of efficacy and students' motivation for learning. For instance, Mojavezi and Tamiz (2012) in their study to investigate the relationship between teacher self-efficacy and students' motivation, found a significant positive correlation between these variables and came to this

Table 1. Relationship between teacher self-efficacy and student motivation

\begin{tabular}{lcc}
\hline & $\begin{array}{c}\text { Overall teacher } \\
\text { self-efficacy }\end{array}$ & $\begin{array}{c}\text { Overall student } \\
\text { motivation }\end{array}$ \\
\hline $\begin{array}{l}\text { Overall teacher } \\
\text { self-efficacy } \\
\begin{array}{l}\text { Pearson } \\
\text { correlation }\end{array} \\
p\end{array}$ & 1 & $0.591^{* *}$ \\
$\mathrm{~N}$ & 25 & 0.002 \\
$\begin{array}{l}\text { Overall student } \\
\text { motivation }\end{array}$ & & 25 \\
Pearson \\
correlation
\end{tabular}

**. Correlation is significant at the 0.01 level (2-tailed)

Table 2. Cohen's (1998) guidelines for interpreting the results of the correlation coefficient

\begin{tabular}{lc}
\hline Interpretation & Correlation value \\
\hline Small correlation & 0.10 to 0.29 \\
Medium correlation & 0.30 to 0.49 \\
Large correlation & 0.50 to 1.0 \\
\hline
\end{tabular}


Table 3. Relationship between teacher personality types and student motivation

\begin{tabular}{lcccccc}
\hline & $\begin{array}{c}\text { Overall student } \\
\text { motivation }\end{array}$ & Neuroticism & Extraversion & Openness & Agreeableness Conscientiousness \\
\hline Overall student motivation & 1 & -0.110 & 0.280 & 0.134 & -0.069 & $0.413^{*}$ \\
$\quad$ Pearson correlation & & 0.601 & 0.176 & 0.522 & 0.744 & 0.040 \\
$p$ & 25 & 25 & 25 & 25 & 25 & 25 \\
$\mathrm{~N}$ & & & & & & \\
\hline
\end{tabular}

*. Correlation is significant at the 0.05 level (2-tailed)

conclusion that teacher self-efficacy positively influences students' motivation. They also concluded that providing teachers with enough opportunities so that they can improve their self-efficacy can lead to an increase in students' motivation and achievement which is of great importance in the process of teaching and learning nowadays. That's because teachers with higher sense of self-efficacy believe in their capabilities for encouraging students to be creative and motivating them to do the academic tasks and the assigned activities very well. They also believe in their capabilities to deal with the questions which are proposed in the class and provide appropriate challenges for the students. They don't seem to have problems adopting different assessment strategies and also strategies for classroom management (Rodríguez, Fernández, Pena, Aguín, \& Menéndez, 2014).

The results are also supportive of Pajares's idea who found that there's a relation between teachers' self-efficacy and their efforts for adopting various methods and materials to develop students' motivation for learning more (Pajares, 1992 as cited in Ghonsooly \& Ghanizadeh, 2013). Similarly, the results are in line with Bandura's observation that teachers with a strong sense of efficacy are more capable of motivating their students and improving their cognitive development (Bandura, 1994 as cited in Mojavezi \& Tamiz, 2012). Finally, according to Dembo and Gibson (1985) low efficacious teachers, in contrast, usually find themselves unable to motivate students and have a positive effect on their performance (as cited in Mazlum, Cheraghi, \& Dasta, 2015).

This study also explored the relationship between EFL teachers' personality types (Big Five personality factors: Neuroticism, Extraversion, Openness to experience, Agreeableness, and Conscientiousness) and students' motivation. The findings of the study showed that there aren't any significant correlations between teachers' personality types 'Neuroticism', 'Extraversion', 'Openness', and 'Agreeableness with their students' motivation at a statistically significant level. However, the findings showed that there is a significant positive statistical correlation between teachers' conscientiousness and their students' motivation. In fact, it was shown that higher conscientiousness in teachers is correlated with higher motivation in students at a statistically significant level. Teachers with higher conscientiousness try to think about things, plan for the future, work hard towards their goals and try not to be impulsive (Dawson \& Shih, 2015). Consequently, they may have more motivated students. Findings show that, if teachers possess more dominant and positive characteristics, especially if they are more conscientious, they can have better interactions with students and make them interested in learning and finally increase their motivation.

The findings concerning the correlation between teachers' personality and students' motivation are in line with the findings of other scholars who have done almost similar studies in other contexts. For example, Zarabian et al. (2015), in their study to investigate the relationship between teachers' personality types and female high school third graders' achievement motivation, found a meaningful relationship between the teachers' personality type and students' achievement motivation. They concluded that teachers' personality consists of desired and undesired characteristics which can contribute to changes in students' motivation. In another study, Jahangiri (2016) found a significant relationship between teachers' personality in using classroom management strategies and students' learning motivation.

\section{CONCLUSION}

Based on the obtained results, it can be concluded that highly efficacious teachers are more successful in motivating their students and improving their cognitive development. However, those who possess a low sense of efficacy favor a "custodial orientation that relies heavily on negative sanctions to get students to study" (Bandura, 1994 as cited in Mojavezi \& Tamiz, 2012, p. 489). It can also be concluded that teachers' personality can be related to students' motivation. In fact, when characteristics such as competence, dutifulness, self-discipline, and conscientiousness are more dominant in teachers, they are more capable in increasing students' interest in learning and making their students more motivated. So, in total, if teachers possess more dominant and positive characteristics, they can have better interactions with students and make them more motivated and interested in learning (Hadian \& Taheri, 2016, Persian reference).

\section{Pedagogical Implications}

The results of the present study are important for teachers, students, language institutes administrators, policy makers, Ministry of Education, and other members of education community who try to improve education.

The results of the current study can help teachers to be more aware of their personality and self-efficacy beliefs and the influence such factors can have on the teaching and learning process and students' achievement and motivation. In fact, when teachers know about their personality types and self-efficacy beliefs, they can adopt the appropriate methods 
in order to make students more interested in learning which finally can lead to increase in their achievement. So, the results of the presen $t$ study can also be beneficial for students.

It is important that educational contexts, as well as language institutes administrators provide opportunities for enhancing teachers' self-efficacy and consequently improving students' achievement and motivation. That's because teachers with higher sense of self-efficacy believe in their capabilities to encourage students to be creative and to motivate them to do the academic tasks and activities as well as possible.

It is also important that language institutes administrators provide personality development programs for teachers which can prepare them for a successful and effective teaching. According to Murray (1972) teachers' personality can have an impact on their behavior in many ways such as their interaction with students, techniques to be used, and learning experiences chosen which means teachers, based on their personality, can make favorable changes to the process of teaching and learning (as cited in Fatemi et al., 2015).

These implications can be practical "if society and policy makers change their view towards teaching and education" (Saeidi \& Kalantarypour, 2011, p. 1566).

\section{Suggestions for Further Studies}

To reach more trustworthy results, it is recommended that the present study be carried out with a larger sample of the EFL teacher population. It is also recommended that a greater geographical region be considered for population in order to be able to reach more dependable and generalizable outcomes. Besides, in this study the data was collected relying on the questionnaires. However, in order to provide a richer description of teachers' efficacy and personality as well as students' motivation, it would be recommended for future researchers to assess classroom observation as well. This will allow in-depth examination of teachers' beliefs about what they can do, their personal characteristics, and also how motivated the students are in the classroom.

\section{ENGLISH REFERENCES}

Akbari, R., Kiany, G. R., Naeeni, I., Naeeni, M. I., \& Karimi Allvar, N. (2008). Teachers' teaching styles, sense of efficacy and reflectivity as correlates of students' achievement outcomes. Iranian Journal of Applied Linguistics, 11(1), 1-28.

Al Haj, A. (2011). Enhancing motivation in the EFL classroom is the solution: A case study of secondary schools of the Gezira State, Sudan. Journal of Language Teaching and Research, 2(3), 524-529.

Alibakhshi, G. (2011). On the impacts of gender and personality types on Iranian EFL teachers' teaching efficacy and teaching activities preferences. Iranian Journal of Applied Linguistics (IJAL), 14(1), 1-22.

Alizadeh, M. (2016). The impact of motivation on English language learning. International Journal of Research in English Educaton, 1(1), 11-15.

Al Kaboody, M. (2013). Second language motivation: The role of teachers in learners' motivation. Journal of Academic and Applied Studies, 3(4), 45-54.
Ayodele, K. O. (2013). The influence of big five personality factors on lecturers-students' interpersonal relationship. The African Symposium: An Online Journal of the African Educational Research Network, 13(1), 28-33.

Bahous, R., Bacha, N., \& Nabhani, M. (2011). Motivating students in the EFL classroom: A case study of perspectives. English Language Teaching, 4(3), 33-43.

Bandura, A. (1977). Self-efficacy: Toward a unifying theory of behavioral change. Psychological Review, 84(2), 191-215.

Bandura, A. (1994). Self-efficacy. Encyclopedia of Human Behavior, 4, 71-81. Retrieved from https://www.uky. edu/ eushe2/Bandura/Bandura1994EHB.pdf

Bandura, A. (1997). Self-efficacy: The exercise of control. New York: Freeman.

Bjurberg, H. (2014). Academic achievement and personality traits: An empirical and neurobiological investigation (Unpublished BS dissertation), University of Skövde, Sweden. Retrieved from https:// www.diva-portal.org/smash/get/diva2:727002/FULLTEXT01.pdf

Cherry, K. (2017). What are the different theories of personality? Retrieved from https://www.verywellmind.com/ personality-psychology-study-guide-2795699

Cohen, A.D. (1998). Strategies for learning and using a second language. New York: Longman.

Costa, P. T., \& McCrae, R. R. (1992). Revised NEO personality inventory (NEO-PI-R) and NEO five-factor inventory (NEO-FFI) professional manual. Odessa, FL: Psychological Assessment Resources.

Dawson, J. R., \& Shih, C. P. (2015). Comparative analysis on personality traits and motivation on international student's academic performance in universities in Taiwan. International Journal of Medical and Health Sciences, 3(4), 209-216.

Fatemi, M.A., Ganjali, R., \& Kafi, Z. (2015). EFL teachers' personality type and their effectiveness in teaching: Investigating the relationship. Global Advanced Research Journal of Educational Research and Review, 4(10), 189-195.

Freeman, C. (2008). Teacher efficacy and its impact on student achievement (Unpublished MA dissertation). Regis University, USA. Retrieved from https://epublications. regis.edu/theses/16

Gavora, P. (2010). Slovak pre-service teacher self-efficacy: Theoretical and research considerations. The New Educational Review, 21(2), 17-30.

Ghazi, S. R., Shahzada, G., \& Ullah, S. (2013). Relationship between students' personality traits and their academic achievement in Khyber Pakhtunkhwa, Pakistan. Journal of Educational and Social Research, 3(2), 437-444.

Ghonsooly, B., \& Ghanizadeh, A. (2011). Self-efficacy and self-regulation and their relationship: A study of Iranian EFL teachers. The Language Learning Journal, 41(1), 1-17. doi: 10.1080/09571736.2011.625096

Gilakjani, A., Leong, L.M., \& Sabouri, N. (2012). A study on the role of motivation in foreign language learning and teaching. International Journal of Modern Education and Computer Science, 4(7), 9-16. 
Hashim, H. N., Mohd, N., Shah Alam, S., \& Yusoff, N. M. (2014). Relationship between teacher's personality, monitoring, learning environment, and students' EFL performance. GEMA Online Journal of Language Studies, 14(1), 101-116. doi: 10.17576/GEMA-2014-1401-07

Jahangiri, M. (2016). Teacher' personality and students' learning motivation. Academic Journal of Psychological Studies, 5(3), 208-214.

Keshavarzi, A., \& Amiri, H. (2016). The effect of teachers' personality and corrective feedback on EFL learners' motivation. Journal of Applied Linguistics and Language Research, 3(5), 118-129.

Leephaijaroen, S. (2016). Effects of the big-five personality traits and organizational commitments on organizational citizenship behavior of support staff at Ubon Ratchathani Rajabhat University, Thailand. Kasetsart Journal of Social Sciences, 37(2), 104-111.

Looney, L. (2003). Understanding teachers' efficacy beliefs. The role of professional community (Unpublished doctoral dissertation). University of Maryland, USA. Retrieved from https://drum.lib.umd.edu/handle/1903/174

Mammadov, S. (2016). Personality predictors of academic achievement in gifted students: Mediation by socio-cognitive and motivational variables (Unpublished doctoral dissertation). College of William and Mary, USA. Retrieved from https://publish.wm.edu/etd/1463413093

Mashhady, H. (2013). Toward an analysis of the bond between emotional intelligence and self-efficacy among EFL teachers. Journal of English Language Teaching and Learning, 5(11), 107-126.

Mayer, J.D. (2007). Asserting the definition of personality. The Online Newsletter for Personality Science, 1, 1-4. Retrieved from http://www.umassmed.personality-arp. org/html/newsletter01/jdm.pdf

Mazlum, F., Cheraghi, F., \& Dasta, M. (2015). English teachers' self-efficacy beliefs and students learning approaches: The role of classroom structure perception. International Journal of Educational Psychology, 4(3), 305-328. doi: 10.17583/ijep.2015.1137

Mojavezi, A., \& Tamiz, M.P. (2012). The impact of teacher self-efficacy on the students' motivation and achievement. Theory and Practice in Language Studies, 2(3), 483-491. doi:10.4304/tpls.2.3.483-491

Moradkhani, S. (2009). The effect of novice English language teachers' self-efficacy and academic degree on students' achievement (Unpublished MA dissertation). Tarbiat Modares University, Iran. Retrieved from http:// docplayer.net/18639887-The-effect-of-novice-english-language-teachers-selfefficacy-and-academic-degree-on-students-achievement.html

Mozaffari, F., \& Ghodratinia, Z. (2015). Extroversion and introversion: The effect of teacher's personality on elementary EFL learners' achievement. IOSR Journal of Humanities and Social Science, 20(9), 61-64. doi: 10.9790/0837-20956164
Naima, B. (2013). The role of intrinsic motivation in developing the students'speaking skill (Unpublished MA dissertation). Université Mohamed Khider de Biskra, Algeria. Retrieved from http://dspace.univ-biskra.dz:8080/ jspui/bitstream/123456789/4756/1/THESIS.pdf

Pajares, F. (2002). Overview of social cognitive theory and of self-efficacy. Retrieved from https://www.uky. edu/ eushe2/Pajares/eff.html

Rashidi, N., \& Moghadam, M. (2014). The effect of teachers' beliefs and sense of self-efficacy on Iranian EFL learners' satisfaction and academic achievement. TESLEJ, 18(2), 1-23.

Rodríguez, S., Fernández, B. R., Pena, R. B., Aguín, I. P., \& Menéndez, R. C. (2014). Teacher self-efficacy and its relationship with students' affective and motivational variables in higher education. European Journal of Education and Psychology, 7(2), 107-120. doi: 10.1989/ ejep.v7i2.183

Saeidi, M., \& Kalantarpour, M. (2011). The relationship between Iranian EFL teachers' self-efficacy and students' language achievement. World Applied Sciences Journal, 15(11), 1562-1567.

Shangarffam, N., \& Poshti, N. R. R. (2011). The relationship among EFL teachers' critical thinking, self-efficacy, and their perception of effective teaching. The Journal of Applied Linguistics, 4(1), 175-207.

Shiri, S. (2015). The application of podcasting as a motivational strategy to Iranian EFL learners of English: A view toward listening comprehension. Advances in Language and Literary Studies, 6(3), 155-165.

Tschannen-Moran, M., \& Hoy, A. W. (2001). Teacher efficacy: Capturing an elusive construct. Teaching and Teacher Education, 17(7), 783-805.

White, D. P. (2009). Differences: The effects of teacher efficacy on student achievement in an urban district (Unpublished doctoral dissertation). Virginia Tech, USA. Retrieved from https://vtechworks.lib.vt.edu/handle/10919/29569

Williams, M., \& Burden, R.L. (1997). Psychology for language teachers: A social constructivist approach. Cambridge: Cambridge University Press.

Zarabian, F., Farajollahi, M., Yousefpour, Z., \& Sajadiseresht, A. (2015). The relationship between teachers' personality types and female high school third graders' achievement motivation in Mashhad. International Research Journal of Applied and Basic Sciences, 9 (6), 815-823.

\section{PERSIAN REFERENCE}

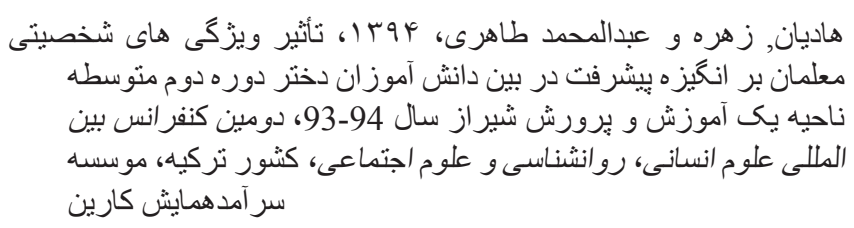

